\title{
PERBANDINGAN HUKUM PENGATURAN STANDARDISASI MENURUT AGREEMENT TBT DAN UNDANG-UNDANG NO. 7 TAHUN 2014 TENTANG PERDAGANGAN
}

\author{
Syukri Hidayatullah \\ Fakultas Hukum Universitas Mulawarman \\ Jalan Sambaliung Kampus Gunung Kelua Samarinda 75119 \\ Email: fhunmul@gmail.com
}

\begin{abstract}
Agreement on Technical Barriers to Trade has been agreed as part of the General Agreement on Tariffs and Trade /GATT and implemented by the WTO member states. In Indonesia, Act No.7/2014 About Trade adopted the system, such as standardization, technical regulations and conformity assessment. This research aims to get the enforcement of standardization according to Act No.7/2014 as compared with the provisions of the Agreement on Technical Barriers to Trade and to obtain the impact of standardization in reducing technical barriers to trade. The research is a normative legal research using comparative approach. The degree of object comparison is discussed using economic analysis of law. The result shows that economic analysis assumes rational behavior of the State to achieve maximum prosperity through multilateral trade agreements. Multilateral agreements are an efficient choice because it produces a universal agreement. Thus, the allocation of norms of standardization in Act No.7/2014 About Trade is assumed to sync with the Agreement on Technical Barrier to Trade, but there is a difference in controlling the equilibrium of treatment. Standardization is still considered to become potential for technical barriers of trade. The essence of this obstacle accounts as internal measures.
\end{abstract}

Key words: standardization, international trade, technical barrier

\begin{abstract}
Abstrak
Agreement on Technical Barriers to Trade disepakati sebagai bagian dari perjanjian General Agreement on Tariffs and Trade (GATT) dan dilaksanakan oleh negara-negara anggota WTO. Di Indonesia, Undang-undang No.7 Tahun 2014 tentang Perdagangan mengatur norma yang diadopsi dari Agreement on Technical Barriers to Trade, yaitu standardisasi, regulasi teknis dan penilaian kesesuaian. Penelitian ini bertujuan untuk mendapatkan hasil pemberlakuan standardisasi menurut Undang-undang No.7 Tahun 2014 tentang Perdagangan yang dibandingkan dengan Agreement on Technical Barriers to Trade dan untuk mendapatkan dampak standardisasi dalam mengurangi hambatan teknis perdagangan. Metode penelitian yang digunakan adalah penelitian hukum normatif. Penelitian ini bersifat deskriptif dengan pendekatan perbandingan hukum. Derajat perbandingan objek penelitian dibahas menggunakan analisis ekonomi terhadap hukum. Hasil penelitian menunjukkan bahwa analisis ekonomi mengasumsikan perilaku rasional Negara untuk mencapai kemakmuran yang sebesar-besarnya melalui perjanjian dagang multilateral. Perjanjian multilateral merupakan pilihan sikap yang efisien karena menghasilkan perjanjian yang universal. Dengan demikian, alokasi norma standardisasi dalam Undang-undang No.7 Tahun 2014 tentang Perdagangan sinkron dengan Agreement on Technical Barrier to Trade. Standardisasi bekerja sebagai instrumen hukum
\end{abstract}


dalam pasar bebas melalui perlindungan lingkungan, keselamatan konsumen, kemanan dan kesehatan publik. Instrumen standardisasi membantu konsumen membandingkan karakteristik produksi dan menambah preferensi bagi konsumen untuk produk sejenis.

Kata kunci: standardisasi, perdagangan internasional, hambatan teknis

\section{Latar Belakang}

Era perdagangan internasional menggambarkan realitas perekonomian dunia dengan desain sistematis yang terintegrasi dalam konfigurasi global, bahkan dapat mengarah secara signifkan untuk memperbaiki perekonomian suatu negara. Efek positif tersebut oleh Joseph Stiglitz dilontarkan sebagai bukti empiris yang pernah dilalui beberapa negara dalam menerapkan kebijakan perdagangan bebas,: ${ }^{1}$

\section{"Trade liberalization created opportunities for economic development, but other factors determined the extent to which those opportunities were realized."}

Ungkapan diatas menegaskan seberapa besarpun pembangunan ekonomi dapat diraih melalui perdagangan bebas, tetap perlu memperhatikan faktor lain yang menentukan cakupan keberhasilannya. Inggris pernah sukses menerapkan keberhasilan terobosan bidang teknologi untuk tampil sebagai negara industri, ekonomi dan industri Jepang yang sukses melalui Restorasi Meiji diraih melalui kebijakan ketat sistem pendidikan, adaptasi tekonologi Barat dan stabilisasi institusional. ${ }^{2}$

Perdagangan bebas dan kesejahteraan saling terkait satu dan lainnya. Perwujudan negara kesejahteraan (welfare state) merupakan salah satu tujuan kebijaksanaan ekonomi internasional termasuk pengendalian perdaganganmelaluisistemproteksi.Kebijakan proteksi ditujukan bagi industri dalam negeri atau untuk melindungi produksi dalam negeri dari persaingan barang impor. Kebijakan tersebut dijalankan dengan pengenaan tarif dan pembatasan kuota. Mekanisme proteksi diatur secara persuasif. Perlindungan tarif dibolehkan untuk menarik pemasukan, akan tetapi agar tidak menjadi hambatan dengan semena-mena menaikkan tarif, kebijakan tersebut tidak boleh berlaku diskriminatif. ${ }^{3}$ Demikian halnya kebijakan pembatasan kuota ekspor dan impor masih diperbolehkan untuk melindungi neraca pembayaran luar negeri dan menjaga keseimbangan devisa. Setelah tujuan perlindungan itu tercapai, kebijakan restriksi kuantitatif harus dikurangi atau bahkan dihapus. ${ }^{4}$

Upaya untuk mengurangi berbagai hambatan dan proteksi perdagangan antar negara mutlak diperlukan. Sebuah sistem

1 Joseph E. Stiglitz and Andrew Charlton, Fair Trade For All How Trade Can Promote Development, (New York: Oxford University Press Inc., 2005), hlm. 11.

2 Ibid., hlm. 12-13.

3 Huala Adolf, Hukum Perdagangan Internasional, (Jakarta: RajaGrafindo Persada, 2013), hlm. 19.

4 Ibid. 
diformalkan dalam serangkaian perjanjian pasca Perang Dunia II, seperti perjanjian multilateral General Agreement on Tariffs and Trade (GATT). Perjanjian tersebut semakin menguatkan komitmen sistem perdagangan internasional yang semakin lama semakin universal. Konsep internasionalisasi perdagangan merupakan tren global yang meninggalkanproteksidagangnasionalmenuju perdagangan internasional yang berpola universal. ${ }^{5}$ Perundingan yang konsisten untuk mengurangi berbagai hambatan perdagangan dapat dicermati dalam salah satu isi perjanjian GATT, yaitu Agreement Technical Barriers To Trade (Agreement TBT) yang memiliki peran sentral dalam menghapus hambatan teknis.

Hambatan teknis terdefinisi oleh istilah hambatan non-tarif sebagai rintangan perdagangan yang bukan tarif. ${ }^{6}$ Inventarisir atas kategori hambatan non-tarif tergolong luas dan kompleks, namun Alan Deardorff dan Robert Stern membuat lima kategori utama, yaitu quantitative restrictions, nontariff charges, government participation in trade, customs procedures and administrative practices, and technical barriers to trade. ${ }^{7}$
Berdasar kategori ini, technical barriers to trade termasuk dalam ruang lingkup hambatan non-tarif.

Agreement TBT berperan mengurangi hambatan teknis perdagangan yang terkait dengan-peraturan teknis (technical regulation), standar (standard), dan prosedur penilaian kesesuaian (conformity assessment procedure). ${ }^{8}$ Ketiga hal tersebut mengatur harmonisasi perdagangan bebas dengan menggunakan standar-standar internasional dalam mengatur simbol, pengepakan, penandaan atau pelabelan yang diterapkan untuk suatu produk menjamin kebijakan domestik yang tidak menghambat kemampuan eksportir mengakses pasar lokal.

SikappemerintahIndonesiamengantisipasi hambatan teknis perdagangan internasional salah satunya adalah dengan mengeluarkan Undang-undang No.7 Tahun 2014 tentang Perdagangan, menggantikan produk hukum kolonial Bedrijfsreglementerings Ordonnantie 1934 yang lebih banyak mengatur perizinan usaha. Berkembangnya pengaruh globalisasi berdampak pada munculnya substansi baru yang diatur. ${ }^{9}$ Hal baru tersebut adalah

5 Clive Schmitthoff menyatakan internasionalisasi GATT “...the general trend of commercial law is everywhere to move away from restrictions of national law to a universal and international conception..." (dalam Huala Adolf, Ibid., hlm. 26).

6 Alan V. Deardorff and Robert M. Stern, Measurement of Non Tariff Barriers, (Ann Arbor: The University of Michigan Press, 2011), hlm. 3.

7 Ibid.

8 Dalam Preambule Agreement TBT disebutkan “... to ensure that technical regulations and standards, including packaging, marking and labelling requirements, and procedures for assessment of conformity with technical regulations and standards do not create unnecessary obstacles to international trade."

9 Dalam Penjelasan Undang-undang Nomor 7/2014 tentang Perdagangan dipaparkan bahwa peraturan perdagangan yang ada selama ini dibuat parsial. Untuk itu perlu perlu dibentuk undang-undang yang menyinkronkan seluruh peraturan perundang-undangan di bidang Perdagangan dalam menyikapi perkembangan globalisasi. 
pengaturan standardisasi yang termuat di Undang-undang No.7 Tahun 2014 tentang Perdagangan.

Standardisasi barang dan jasa di dalam Undang-undang No.7 Tahun 2014 tentang Perdagangan menurut Pasal 5 dan Pasal 38 adalah kebijakan perdagangan Pemerintah, baik dalam perdagangan dalam negeri dan perdagangan luar negeri. Sebagai sebuah kebijakan, program standardisasi perlu dikendalikan agar tidak menimbulkan proteksi yang menghambat. Standardisasi yang cenderung protektif dapat diterapkan untuk melindungi kepentingan nasional, namun menghambat ekspor Negara-Negara mitra dagang ke Indonesia. Begitu pula sebaliknya, jika program standardisasi cenderung diterapkan longgar, aliran barang dan jasa impor akan mengancam kepentingan umum, menekan produksi dan komoditas dalam negeri serta posisi tukar mata uang.

Standardisasi dapat menjadi permasalahan apabila dimaknai sebagai kebijakan ketat atau kebijakan longar sehingga diperlukan perbandingan hukum untuk menganalisa harmonisasi konsep standardisasi tanpa menjadi hambatan teknis perdaagangan bebas.

Aspek-apek yuridis normatif standardisasi akan dikaji dengan menyusun suatu perbandingan norma hukum antara yang diatur menurut Undang-undang No.7 Tahun 2014 tentang Perdagangan dengan yang diatur menurut Agreement TBT. Sebagai pendukung perbandingan, akan digunakan analisis ekonomi terhadap hukum (analysis economic of law). Agreement TBT akan dievaluasi menurut parameter analisis ekonomi terhadap hukum untuk kemudian dibandingkan dengan standardisasi menurut Undang-undang No.7 Tahun 2014 tentang Perdagangan.

Sehubungan latar belakang diatas, dapat dirumuskan beberapa permasalahan sebagai berikut:

1. Bagaimana analisis ekonomi terhadap hukum dalam Agreement on Technical Barrier to Trade dibandingkan dengan standardisasi yang diatur dalam Undangundang No.7 Tahun 2014 tentang Perdagangan?

2. Bagaimana efektivitas standardisasi sebagai instrumen hukum untuk mengurangi hambatan teknis perdagangan bebas ?

Penggunaan metode sangat tergantung pada jenis penelitian yang dipergunakan. Penelitian ini merupakan jenis penelitian hukum. Penelitian hukum merupakan suatu kegiatan ilmiah yang didasarkan pada metode, sistematika dan pemikiran tertentu yang bertujuan untuk mempelajari satu atau beberapa gejala hukum tertentu dengan jalan menganalisanya atau juga diadakan pemeriksaan mendalam terhadap fakta hukum tersebut serta seyogyanya selalu mengkaitkannya dengan arti-artiyangmungkin dapat diberikan pada hukum. ${ }^{10}$ Penggolongan penelitian hukum kali ini merupakan penelitian hukum normatif. Menurut Soerjono 
Soekanto dan Sri Mamuji, penelitian hukum normatif didefenisikan sebagai penelitian yang dilakukan dengan cara meneliti bahan pustaka atau data sekunder belaka. ${ }^{11}$ Dengan demikian penelitian ini merupakan penelitian hukum normatif (normative legal research) yang akan mencari dan mengumpulkan serta menganalisa bahan-bahan hukum, baik bahan hukum primer maupun bahan hukum sekunder sebagai bagian dari studi kepustakaan.

Penelitian hukum dapat ditinjau dari sudut sifatnya, yang mencakup penelitian eksploratoris (penjelajahan), penelitian deskriptif dan penelitian eksplonatoris. ${ }^{12}$ Sesuai dengan karakterisktik pada tujuan perumusan masalah untuk mendapatkan hasil perbandingan dan implikasi penerapan satndardisasi barang dan jasa, maka penelitian ini bersifat deskriptif. Dilakukan untuk melukiskan sesuatu (di daerah tertertu pada saat tertentu), memilki data awal yang akan diteliti dan telah terdapat landasan teori yang relevan dengan sifat penelitian.

Penelitian diartikan sebagai usaha untuk mengadakan hubungan dengan yang diteliti atau metode-metode untuk mencapai pengertian tentang masalah penelitian. ${ }^{13}$ Seiring dengan pendapat tersebut, maka menurut Peter Mahmud Marzuki terdapat lima pendekatan dalam penelitian hukum normatif sebagai berikut: ${ }^{14}$

a. Pendekatan Undang-Undang (Statute approach)

b. Pendekatan Kasus (Case approach)

c. Pendekatan Sejarah (Historical approach)

d. Pendekatan Perbandingan (Comparative approach)

e. Pendekatan Konseptual (Conceptual approach)

Sesuai dengan tema yang akan diteliti mengenai perbandingan standardisasi barang dan jasa antara Undang-undang No.7 Tahun 2014 tentang Perdagangan dan lampiran GATT mengenai Agreement on Technical Barriers To Trade, maka pendekatan yang akan digunakan dalam penelitian ini adalah perbandingan hukum. Menurut Sunaryati Hartono, objek yang hendak dibandingkan merupakan suatu comparability atau memiliki tingkat tertium comparationis untuk kemudian ditentukan unsur-unsur persamaannya dan unsur perbedaannya. ${ }^{15}$ Derajat perbandingan atau comparability objek penelitian dapat berbeda-beda tergantung unsur yang diteliti, seperti dari aspek hukum struktur hukum, fungsi hukum ataupun akibat hukumnya.

11 Salim HS dan Erlies Septiana Nurbaini, Penerapan Teori Hukum pada Penelitian Tesis dan Disertasi, Cetakan Ke-2, (Jakarta: RajaGrafindo Persada, 2013), hlm. 12.

12 Soerjono Soekanto, op.cit., hlm. 50.

13 Salim HS dan Erlies Septiana Nurbaini, op.cit., hlm. 17.

14 Peter Mahmud Marzuki, Penelitian Hukum, (Jakarta: Kencana Prenada Media, 2006), hlm. 93.

15 Sunaryati Hartono, Penelitian Hukum di Indonesia pada Akhir Abad ke 20, (Bandung: Alumni, 1994), hlm. 170. 
Adapun tertium comparationis merupakan tolak ukur untuk menunjukkan adanya kesesuaian atas pranata-pranata atau kaidahkaidah yang dibandingkan. Persamaan tugas dan tujuan suatu pranata hukum maupun kaidah hukum inilah yang menunjukkan adanya tertium comparationis. ${ }^{16}$

\section{Pembahasan}

\section{A. Tinjauan Yuridis Hambatan Teknis Dalam Agreement on Technical Barrier to Trade}

Ketentuan-ketentuan prinsipil mengenai standardisasi dan perlindungan bagi lingkungan hidup pada awalnya pernah dibahas dalam agenda pertemuan Organization for Economic Cooperation and Development (OECD) pada tahun 1972. Agenda ini memiliki tema Guiding Principles Concerning the International Economic Aspects of Environmental Policies. ${ }^{17}$ Meskipun upaya ini tidak mengikat diantara para Negara peserta dan tidak digunakan sebagai instrumen hukum, namun dapat memberikan gagasan awal untuk dirintis dalam perundingan GATT 1947.

Gagasan awal untuk mengeliminir kontra produktivitas naskah teks GATT 1947 itu sendiri dinyatakan oleh Michael J.Trebilcock sebagai berikut: ${ }^{18}$
"The original GATT as adopted in 1947 does not contain provisions that directly restrict the 'Contracting Parties' freedom to adopt environmental, health and safety standards."

Sifat instrumen hukum dalam GATT 1947 tidak secara langsung memuat aturan perlindungan lingkungan, kesehatan dan standar karena kaidah-kaidah tersebut tersebar dalam beberapa Pasal dan diantaranya berlawanan satu sama lain, tanpa memiliki kepastian penafsiran yang tunggal. Kritisnya penafsiran ini akan berujung pada kesulitan para pihak untuk menyetujui dan menerapkannya di Negara masing-masing, sehingga menimbulkan potensi menghambat perdagangan. Setiap Negara memiliki kedaulatan hukum untuk mengatur mekanisme perlindungan produk nasional dengan penafsiran yang potektif sehingga menghambat impor maupun ekspor perdagangan.

Hal senada dinyatakan oleh Arthur E. Appleton dalam mengalisis kebijakan The Agreement on Technical Barriers to Trade. GATT 1947 tidak mengatur regulasi teknis dan standar secara detail, meskipun terminologi standar pernah disebut dalam Pasal III (4), Pasal XI (2) dan Pasal XX. ${ }^{19}$

17 Michael J.Trebilcock and Robert Howse, The Regulation of International Trade Second Edition, (London: Routledge, 1999), hlm. 132.

18 Michael J.Trebilcock and Robert Howse, Ibid., hlm. 133.

19 Arthur Appleton, The World Trade Organization:Legal, Economic and Political Analysis Vol.1, (New York: Springer Science+Business, 2005), hlm. 374. 
Sebaran beberapa pasal dalam naskah teks GATT 1947 yang dapat menimbulkan konflik hambatan perdagangan bebas diantaranya Pasal III ayat 4 yang mewajibkan perlakuan setara antara produk nasional dengan produk impor berlawanan dengan Penjelasan Pasal III yang menyatakan bahwa tindakan yang diambil dalam memberlakukan produk nasional dan produk impor dianggap sebagai tindakan internal. ${ }^{20}$ Berikutnya, Pasal XX diterjemahkan secara sempit untuk membatasi perlindungan lingkungan, keamanan dan kesehatan sehingga menghambat perdagangan bebas. ${ }^{21}$ Sedangkan Arthur Appleton menambahkan, bahwa perkecualian Pasal XX GATT 1947 menjadi justifikasi pada pihak terikat untuk memaknai regulasi dan standardisasi sebatas tindakan yang jika diperlukan untuk melindungi manusia, hewan, tumbuhan dan kesehatan. ${ }^{22}$

Pengesahan berdirinya World Trade Organization (WTO) merupakan titik kulminasi dari serangkaian perundingan sebelumnya, yang juga sekaligus penetapan untuk memuat beberapa perjanjian yang ada selama Putaran Uruguay berlangsung. Seperti yang dinyatakan oleh Michelle Sanson: ${ }^{23}$

"Known as the Marrakesh Agreement, but officially titled 'The Final Act Embodying the Results of the Uruguay Round of Multilateral Trade Negotiations', the WTO Agreement contains a number of agreements reached during the course of the Uruguay Round."

Menurut Trebilcock, Putaran Uruguay menghasilkan dua perjanjian baru sebagai elaborasi dari Standards Code hasil Putaran Tokyo 1979. Selengkapnya dinyatakan: ${ }^{24}$

"The Uruguay Round elaborated the Tokyo Round Standards Code into two new agreements governing standards. The Agreement on Sanitary and Phytosanitary Measures (SPS Agreement) addresses measures designed to protect human, animal and plant life, and health. The Technical Barriers to Trade greement (Agreement TBT) covers other technical standards and measures not covered by the SPS Agreement. Under the 'umbrella' provisions of the WTO, all Parties to the GATT are obligated to adhere to both of these Agreements."

The Agreement on Sanitary and Phytosanitary Measures (SPS Agreement) dan The Technical Barriers to Trade Agreement (Agreement TBT) merupakan suatu kesatuan perjanjian yang utuh dan saling melengkapi. Jika SPS Agreement dirancang mengatur perlindungan bagi kehidupan ekologi dan lingkungan, maka Agreement TBT mengakomodir ketentuan standar teknis yang tidak diatur dalam SPS Agreement.

Ketentuan Agreement TBT bekerja melalui tiga konsep yang tidak termuat dalam SPS Agreement, yaitu regulasi teknis, standar dan

20 Michael J.Trebilcock and Robert Howse, op.cit., hlm. 133.

21 Michael J.Trebilcock and Robert Howse, Ibid.

22 Arthur Appleton, op.cit., p. 375.

23 Michelle Sanson, Essential International Trade Law, (Sydney: Cavendish, 2002), p. 16.

24 Michael J.Trebilcock and Robert Howse, op.cit., p. 135. 
prosedur penilaian kesesuaian dan berlaku untuk semua produk. ${ }^{25}$ Definisi ketiga konsep ini dapat ditemui dalam Annex 1 Agreement TBT. Secara tematik, substansi dari kaidahkaidah Agreement TBT seperti regulasi teknis, standar dan penilaian kesesuaian dapat ditabulasi seperti pada Tabel 1 .

Aplikasiregulasiteknistersusundaritigahal pokok, yaitu identifikasi produk, karakteristik produk dan kewajiban penerapan. ${ }^{26}$ Sebuah produk diidentifikasi dengan memuat dokumen karakteristik yang bersifat wajib. Dokumen tersebut wajib mencantumkan terminologi, simbol, pengemasan dan pelabelan yang menggambarkan dengan tepat komposisi sebuah produk dari bidang-bidang tertentu yang telah diidentifikasi sebelumnya, seperti produk perkebunan, agrikultur, holtikultura, industri manufaktur, elektronik mekanikal dan sebagainya. Bentuk regulasi teknis merupakan potensi terbesar untuk membatasi perdagangan internasional. Menurut Arthur Appleton, karakteristik produk yang tidak memenuhi persyaratan aplikasi regulasi teknis akan dilarang dijual. ${ }^{27}$

Perumusan standar pada dasarnya serupa dengan regulasi teknis kecuali sifat berlakunya yang sukarela. Norma sukarela ini dipertimbangkan karena beberapa institusi mengeluarkan banyak peraturan dalam membentuk standar yang tidak mengikat bagi pelaku pasar. ${ }^{28}$ Sebagai contoh sebuah produk elektronik membutuhkan standardisasi voltase, atau sebuah perusahaan manufaktur membutuhkan ukuran baut dan mur yang terstandardisasi sehingga produk tersebut dapat mudah diperbaiki dan di bongkar pasang dimana saja tanpa harus berlaku wajib menggunakan salah satu produk saja selama produk tersebut memenuhi karakteristik voltase atau ukuran baut. Penerapan yang berbeda ini diartikan bahwa sekalipun Agreement TBT membedakan perlakuan sifat wajib dan sukarela, kekuatan mengikatnya kembali ditentukan oleh status formal. Formalitas tersebut ditentukan oleh yurisdiksi domestik.

Conformity assessment procedures atau prosedur penilaian kesesuaian merupakan kaidah ketiga dari mekanisme hambatan teknis perdagangan. Penilaian tersebut pada umumnya dilakukan dengan tiga cara: ${ }^{29}$

a. Penilaian satu pihak, dilakukan dengan cara deklarasi pemasok secara unilateral. Kesesuaian tersebut berdasarkan penilaian dan pengendalian mandiri (selfassessment and self-control).

b. Penilaian pihak kedua, dilakukan oleh pembeli atau pengimpor atau oleh lembaga inspeksi/pengujian.

25 "Agreement TBT applies to all products, including industrial and agricultural products, but does not include SPS measures. It covers technical regulations, standards and conformity assessment procedures, as defined in Annex 1 of the Agreement." Dalam Trebilcock, Ibid.

26 Michaels Koebele, Max Planck Commentaries on World Trade Law volume 3, (Leiden: Koninklijke Brill NV, 2007), hlm. 187.

27 Arthur Appleton, op.cit., hlm. 377.

28 Michaels Koebele, op.cit., hlm. 190.

29 Michaels Koebele, Ibid., hlm. 193. 
Tabel 1. Pembagian kaidah Agreement TBT

\begin{tabular}{|l|l|l|l|}
\hline \multicolumn{1}{|c|}{ Kaidah } & \multicolumn{1}{c|}{ Bentuk } & \multicolumn{1}{c|}{ Sifat } & \multicolumn{1}{c|}{ Tata Cara } \\
\hline Regulasi Teknis & $\begin{array}{l}\text { Dokumen Wajib } \\
\text { (Mandatory) }\end{array}$ & $\begin{array}{l}\text { Menetapkan } \\
\text { karakteristik produk, } \\
\text { proses dan metode } \\
\text { produksi. }\end{array}$ & $\begin{array}{l}\text { Persyaratan } \\
\text { terminologi, simbol, } \\
\text { pengemasan, penandaan } \\
\text { atau pelabelan. }\end{array}$ \\
\hline Standar & $\begin{array}{l}\text { Dokumen Tidak } \\
\text { Wajib (Voluntary) }\end{array}$ & $\begin{array}{l}\text { Menjadi wajib bila } \\
\text { ditetapkan oleh badan } \\
\text { yang berwenang } \\
\text { berdasar konsesus } \\
\text { internasional. }\end{array}$ & $\begin{array}{l}\text { Persyaratan } \\
\text { terminologi, simbol, } \\
\text { pengemasan, penandaan } \\
\text { atau pelabelan,pedoman } \\
\text { atau tata cara. }\end{array}$ \\
\hline $\begin{array}{l}\text { Penilaian } \\
\text { Kesesuaian }\end{array}$ & $\begin{array}{l}\text { Prosedur yang } \\
\text { digunakan secara } \\
\text { langsung atau } \\
\text { secara tidak } \\
\text { langsung }\end{array}$ & $\begin{array}{l}\text { Menentukan } \\
\text { regulasi teknis dan } \\
\text { standar yang memenuhi } \\
\text { persyaratan atau tidak } \\
\text { memenuhi persyaratan. }\end{array}$ & $\begin{array}{l}\text { Uji coba, inspeksi, } \\
\text { evaluasi,verifikasi, } \\
\text { registrasi,akreditasi atau } \\
\text { kombinasinya. }\end{array}$ \\
\hline
\end{tabular}

\section{Sumber: Diolah dari naskah Agreement TBT}

c. Penilaian pihak ketiga, dilakukan secara independen oleh sebuah lembaga baik yang ditunjuk pemasok atau pembeli.

Tahapan penilaian berikutnya adalah pengakuan formal. Hasil penilaian kesesuaian termuat dalam tanda sertifikasi yang tertera pada produk atau kemasannya. Selain sertifikasi, proses penilaian sebuah produksi dapat pula mendapatkan pengakuannya dengan diterbitkannya akreditasi. Akreditasi menjadi penting ketika tidak ada otoritas resmi yang berada dalam posisi untuk menilai kualitas dan pengetahuan atas suatu regulasi teknis atau standar tertentu. ${ }^{30}$

\section{B. Integrasi Norma Standardisasi Nasional}

Integrasi standardisasi internasional ke wilayah regulasi perdagangan nasional menarik untuk dicermati. Sejak tahun 1964, Indonesia telah mengatur standardisasi di bidang industri melalui Peraturan Pemerintah Nomor 9 Tahun 1964 Tentang Standardisasi Industri. Di era Demokrasi Terpimpin, Presiden Soekarno membentuk Dewan Perancang Nasional yang dikepalai oleh Mohammad Yamin. Dewan tersebut diberi amanat untuk menyusun Rencana Pembangunan Semesta Delapan Tahun. ${ }^{31}$ Orientasi Soekarno untuk memulihkan ekonomi Indonesia berpaling pada sektor industri dasar. Beberapa pabrik berhasil dibangun, seperti PT Pusri di Palembang dan pabrik semen besar pertama di Gresik (PT Semen Gresik). ${ }^{32}$

Regulasi standardisasi nasional telah mengalami pergeseran paradigma, dari yang semula dimanfaatkan untuk menciptakan

30 Michaels Koebele, Ibid.

31 Thee Kian Wie (Ed), Pelaku Berkisah Ekonomi Indonesia 1950-an sampai 1990-an, Cetakan Ke-1, (Jakarta: Kompas, 2005), hlm. xii.

32 Thee Kian Wie (Ed), Ibid. 


\section{Gambar 1. Pola Keterkaitan Standarisasi, Standar dan SNI}

\section{Standardisasi $\cdot$ Merumuskan Standar}

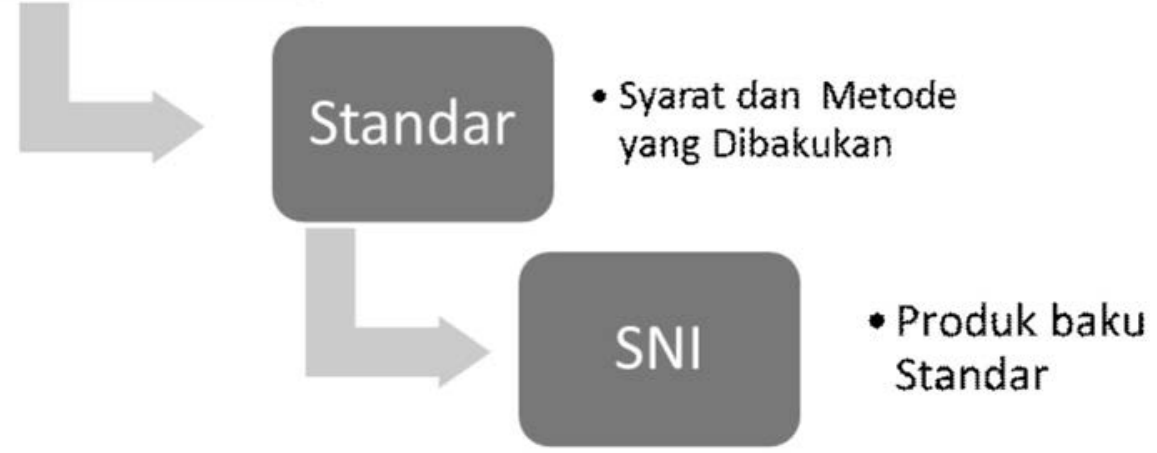

Sumber: Data Primer, diolah, 2007

harmonisasi industri berkembang menjadi sarana yang strategis dalam perdagangan.

Definisi standardisasi dapat diketahui dalam Pasal 1 Angka 9 Undang-undang No.7 Tahun 2014, sebagai berikut:

Standardisasi adalah proses merumuskan, menetapkan, menerapkan, memelihara, memberlakukan, dan mengawasi Standar yang dilaksanakan secara tertib dan bekerja sama dengan semua pihak.

Pengertian Standar seperti yang terdapat dalam rumusan Standardisasi diatas dapat dilihat dalam Pasal 1 Angka 8 Undang-undang No. 7 Tahun 2014 sebagai berikut:

Standar adalah persyaratan teknis atau sesuatu yang dibakukan, termasuk tata cara dan metode yang disusun berdasarkan konsensus semua pihak/Pemerintah/ keputusan internasional yang terkait dengan memperhatikan syarat keselamatan, keamanan, kesehatan, lingkungan hidup, perkembangan ilmu pengetahuan dan teknologi, pengalaman, serta perkembangan pada masa kini dan masa depan untuk memperoleh manfaat yang sebesar-besarnya.

Norma-norma standar diatas memuat suatu istilah yang disebut sebagai pembakuan persyaratan teknis. Istilah ini selanjutnya disebut sebagai Standar Nasional Indonesia (SNI) yang pengertiannya dapat dilihat dalam Pasal 1 Angka 10 Undang-undang No.7 Tahun 2014 sebagai berikut:

Standar Nasional Indonesia yang selanjutnya disingkat SNI adalah Standar yang ditetapkan oleh lembaga yang menyelenggarakan pengembangan dan pembinaan di bidang Standardisasi.

Pengertian Standardisasi, Standar dan SNI seperti yang telah diutarakan diatas memiliki suatu konsistensi pola yang sistematis. Standardisasi dirumuskan sebagai proses untuk merumuskan dan menerapkan Standar, selanjutnya Standar dirumuskan sebagai 
persyaratan teknis, metode dan tata cara yang dibakukan. Pembakuan tersebut pada akhirnya dirumuskan dan ditetapkan sebagai Standar Nasional Indonesia (SNI) sekaligus menjadi kewenangan lembaga yang mengembangkan Standardisasi, yaitu Badan Standardisasi Nasional.

Keterkaitan pola tersebut dapat diilustrasikan dalam skema (Gambar 1)

\section{Analisis Ekonomi Terhadap Agreement on Technical Barrier to Trade}

Sebagai konsekuensi yuridis menjadi anggota World Trade Organization (WTO), Indonesia mengadopsi normanorma standardisasi internasional sejak dikeluarkannya Pemerintah Nomor 102 Tahun 2000 Tentang Standardisasi Nasional hingga ditegaskan lagi dalam Undang-undang No.7 Tahun 2014 tentang Perdagangan. Alokasi norma, kaidah, proses dan kelembagaan standardisasi, regulasi teknis dan penilaian kesesuaian menurut Agreement on Technical Barrier to Trade telah bertransformasi ke dalam regulasi perdagangan nasional.

Transformasi hukum merupakan unsur pokok dalam proses globalisasi yang terjadi secara langsung dari adanya jaringan globalisasi lokal dan lokalisasi global. ${ }^{33}$ Terdapat tiga macam transformasi hukum yang dapat dikemukan, yaitu transnasionalisasi peraturan hukum negara bangsa yang berbeda, hukum integrasi regional dan lex mercatoria. ${ }^{34}$ Perbedaan hukum antar Negara dipengaruhi secara kuat oleh perubahan-perubahan hukum di bidang ekonomi, transaksi perdagangan, unifikasi hukum dan modernisasi hukum untuk diterapkan oleh negara-negara di dunia. ${ }^{35}$ Unifikasi hukum di bidang perdagangan melalui skema standardisasi terwujud melalui penerapan Agreement TBT, yang meskipun terintegrasi melalui harmonisasi hukum namun memiliki kompleksitas tersendiri.

Kerumitan dalam menerapkan standardisasi barang dan jasa adalah menjaga keseimbangan perlakuan. ${ }^{36}$ Melalui Agreement TBT, harmonisasi perdagangan dapat diprediksi agar tidak menimbulkan hambatan. Akan tetapi, hambatan inijuga dapat dimanfaatkan sebagai instrumen protektif untuk melindungi kepentingan nasional. Untuk mereduksi kerumitan tersebut, dapat digunakan analisis ekonomi terhadap hukum, demi mencapai keputusan yang rasional dalam memaksimalkan manfaat regulasi standardisasi. Analisis ekonomi terhadap hukum memandang hukum dari perspektif

33 An An Chandrawulan, Hukum Perusahaan Multinasional, Liberalisasi Hukum Perdagangan Internasional dan Hukum Penanaman Modal, (Bandung: Alumni, 2011), hlm. 109.

34 Bonaventura De Sousa Santos, dalam An An Chandrawulan, Ibid.

35 An An Chandrawulan, Ibid.

36 "The preamble evidences that the drafters of the Agreement TBT sought to achieve a balance between assuring that technical regulations, standards and conformity assessment procedures do not become unnecessary obstacles... and allowing Members the regulatory autonomy to protect legitimate interests through the use of these potential barriers." Dalam Arthur Appleton, The World Trade Organization:Legal, Economic and Political Analysis Vol.1, (New York: Springer Science+Business, 2005), hlm. 374. 
ekonomi. Beberapa aspek fundamental dari ekonomi akan dikaji terlebih dahulu sebelum dielaborasi menjadi analisa hukum.

Pendekatan hukum dari ekonomi menurut Steven Shavell terbagi atas dua analisis yang mendasar, yaitu deskriptif dan normatif. ${ }^{37}$ Kedua analisis ini dirancang oleh Shavell untuk memberi klarifikasi teoritis yang tegas antara hukum dan perilaku sosial, sebelum keduanya melebur menjadi analisis ekonomi terhadap hukum. Model analisa deskriptif menjabarkan efek aturan hukum, sedangkan model analisa normatif menjabarkan ekspektasi masyarakat terhadap hukum. ${ }^{38}$

Analisis deskriptif mengasumsikan terdapat peran individu yang rasional. Bahwa tiap orang bersikap dan berpandangan ke depan untuk memaksimalkan harapannya, maka pengaruh aturan hukum bagi perilaku masyarakat dapat dipastikan. ${ }^{39}$ Dengan kalimat lain, efek hukum mempengaruhi tingkat rasionalitas masyarakat. Sebagai contoh, adanya acaman denda bagi pengemudi mobil yang tidak menggunakan sabuk pengaman akan mempengaruhi perilaku pengendara. Ketentuan efek denda sebagai ancaman hukuman, akan membuat masyarakat dipastikan bersikap rasional dengan cara menggunakan sabuk pengaman setiap kali berkendara.

Analisis normatif mengacu pada konsep kesejahteraan masyarakat. ${ }^{40}$ Dan karenanya analisis normatif bersifat kondisional karena aturan hukum yang akan diterapkan tergantung pada kriteria kesejahteraan yang dipertimbangkan. ${ }^{41}$ Untuk mendalami ukuran yang digunakan, maka Steven Shavell mengkritisi bahwa kriteria kesejahteraan tidak dipandang dari sudut ekonomis, melainkan diukur dari tinggi rendahnya ekspektasi kesejahteraan seperti apa yang diinginkan masyarakat. $^{42}$

Robert Cooter dan Thomas Ulen menyatakan bahwa analisis ekonomi terhadap hukum merupakan upaya untuk menjawab celah-celah hukum yang ada. ${ }^{43}$ Celah tersebut diisi dengan analisis ekonomi untuk memprediksi pengaruh sanksi hukum atas perilaku. Aspek ekonomi pada umumnya mengajukan teori perilaku untuk memprediksi bagaimana masyarakat merespon hukum berdasar asumsi ekonomi yang fundamental,

37 Steven Shavell, Foundation of Economic Analysis of Law, (Cambridge, Massachusetts: The Belknap Press of Harvard University Press, 2004), p. 1.

38 Steven Shavell, Ibid. Lebih lanjut dikatakan Steven Shavell "The first type is descriptive, concerning the effects of legal rules, ... the other type of question is normative, pertaining to the social desirability of legal rules."

39 Steven Shavell, Ibid. "Given the characterization of individuals' behavior as rational, the influence of legal rules on behavior can be ascertained."

40 Steven Shavell, Ibid., hlm. 2. "The evaluation of social policies, and thus of legal rules, will be undertaken with reference to a stated measure of social welfare."

41 Steven Shavell, Ibid.

42 Steven Shavell, Ibid.

43 "Like the rabbit in Australia, economics found a vacant niche in the "intellectual ecology" of the law and rapidly filled it." Robert Cooter and Thomas Ulen, Law and Economics Sixth Edition, (Boston MA: Pearson, 2012), p. 3. 
yaitu maximization, equilibrium, dan efficiency. ${ }^{44}$

Maksimalisasi merupakan perilaku yang rasional bahwa seseorang akan memenuhi kebutuhannya secara maksimal. Meskipun terdapat hambatan, maka perilaku tersebut akan beralih mencari alternatif terbaik menyesuaikan kemampuan yang tersisa. ${ }^{45}$ Ekuilibrium atau keseimbangan adalah pola interaksi yang tetap, kecuali terganggu oleh kekuatan dari luar. ${ }^{46}$ Interaksi tersebut cenderung mengarah pada sebuah keseimbangan terlepas dari peristiwa yang beragam, seperti pernikahan, pemilihan umum, transaksi pasar atau perusahaan. ${ }^{47}$

Efisiensi menyangkut kepuasan atas preferensi yang dialami individu. Pilihan tersebut diputuskan dalam keadaan situasional. Pencapaian efisiensi terkait situasi khusus tersebut dinamakan Pareto efficiency atau efisiensi alokatif. ${ }^{48}$ Prinsip ini berjalan dengan cara memutus alokasi pilihan yang seefisien mungkin tanpa mengakibatkan inefisiensi bagi orang lain.

Pendekatan analisis ekonomi terhadap bidang-bidang hukum dapat diterapkan berdasar klasifikasi yang disusun dalam Handbook of Law and Economics. ${ }^{49}$ Terdapat tiga sistematika hukum yang dianalisis secara ekonomi, yaitu: ${ }^{50}$

1. Bagian I adalah building block sistem hukum yang terdiri atas hukum properti; hukum kontrak; litigasi (termasuk prosedur hukum sipil) dan penegakan hukum publik (termasuk hukum pidana).

2. Bagian II adalah tema penting lain dari hukum yang terdiri dari hukum korporasi; hukumkepailitan; hukumlaranganpraktek monopoli; hukum perburuhan; hak atas kekayaan intelektual; hukum lingkungan dan hukum internasional.

3. Bagian III merupakan tema pelengkap yang terdiri atas kaidah dan hukum dan politik ekonomi dan hukum.

Hukum perdagangan internasional sebagai salah satu bagian dari ruang lingkup hukum internasional merupakan topik hukum yang dapat dianalisis secara ekonomi. Bidang hukum internasional pada umumnya terbagi menjadi dua sub bidang, yaitu hukum publik internasional dan hukum perdata internasional. Hukum publik internasional mengacu pada isi hukum yang mengatur hubungan antar negara. Adapun hukum perdata internasional mengatur kaidah hukum mana yang digunakan dalam hubungan

44 Robert Cooter and Thomas Ulen, Ibid., p. 12.

45 Robert Cooter and Thomas Ulen, Ibid., p. 13.

46 Robert Cooter and Thomas Ulen, Ibid., "An equilibrium is a pattern of interaction that persists unless disturbed by outside forces"

47 Robert Cooter and Thomas Ulen, Ibid.

48 Robert Cooter and Thomas Ulen, Ibid., p. 14.

49 Mitchell Polinsky dan Steven Shavell (Ed), Handbook of Law and Economics Vol.1, (Oxford: Elsevier, 2007), p. xi. "The purpose of this Handbook is to provide economists with a systematic introduction to and survey of research in the field of law and economics"

50 Mitchell Polinsky dan Steven Shavell (Ed), Ibid. 
antar warga negara. ${ }^{51}$ Berbeda dengan hukum perdata internasional, hukum publik internasional timbul dari adanya kesepakatan antar negara. ${ }^{52}$ Analisa ekonomi terhadap hukum publik internasional mengidentifikasi bahwa faktor Negara dan perjanjian sebagai aspek deskriptif (perilaku rasional Negara) dan aspek normatif (kebiasaan dan perjanjian internasional) dari perspektif ekonomi.

Dalam analisa ekonomi, Negara adalah pelaku, yang diasumsikan bersikap rasional untuk memberikan ksejahteraan bagi rakyatnya. Suatu Negara memiliki beberapa pilihan dari hasil interaksi dengan Negara lain untuk kemudian berlaku rasional atas kepentinganya sendiri, yaitu memutuskan pilihan mana yang terbaik diantara interaksi tersebut dalam memaksimalkan kesejahteraannya. Dinyatakan lebih lengkap oleh Alan Sykes: ${ }^{53}$

"Positive economic analysis of international legal regimes conventionally proceeds from an assumption that states behave as if they are rational maximizers over some set of preferences regarding the outcomes of their interaction."

Jack Goldsmith dan Eric Posner memiliki pendapat yang korelatif, khususnya saat menganalisa sikap rasional Negara terhadap kebiasaan internasional dan perjanjian internasional. $^{54}$ Asumsi bahwa Negara bersikap rasional (secara deskriptif) untuk memaksimalkan kepentingannya secara normatif yang termanifestasi dalam kebiasaan hukum internasional (customary international law) dan perjanjian atau pakta (treaty). ${ }^{55}$ Fokus analisis yang akan disarikan dari Goldsmith dan Posner berikut adalah analisa normatif kebiasaan dan perjanjian internasional.

Kebiasaan hukum internasional memuat makna kebiasaan umum yang dijalankan sebuah Negara untuk mengikuti naluri kewajiban hukum. Makna tersebut terdiri atas dua elemen, yaitu adanya kebiasaan yang sudah diketahui umum serta bersifat seragam; dan Negara harus terlibat dalam kebiasaan hukum tersebut. Elemen kedua, yakni kebiasaan hukum mengacu kepada maksim opinio juris, bahwa alasan Negara dalam bertindak diukur sesuai dengan perilaku yang teratur atau seringkali merupakan unsur psikologi kebiasaan hukum internasional.

Sebagai acuan psikologis, opoinio juris memiliki keterbatasan dalam menjelaskan hubungannya untuk terwujud menjadi kewajiban hukum yang mengikat, atau

51 Definisi diatas bekerja jika adanya unsur luar negeri (foreign element) dalam titik pertalian dari kaidah-kaidah hukum dua atau lebih negara. Sudargo Gautama, Pengantar Hukum Perdata Internasional, Cetakan Ke-5, (Bandung: Binacipta, 1987), hlm. 21.

52 "The genesis of public international law necessarily differs from that of domestic law....Instead, public international law arises only by agreement among states." Dalam Mitchell Polinsky dan Steven Shavell (Ed), op.cit., p. 760.

53 Mitchell Polinsky dan Steven Shavell (Ed), Ibid., p. 762.

54 "Our theory of international law assumes that states act rationally to maximize their interests". Jack L. Goldsmith, Eric A. Posner, The Limits of International Law, (New York: Oxford University Press), 2005, p. 7.

55 Steven Shavell, loc.cit. 
kebiasaan yang teratur tidak serta merta membuatnya mengikat bagi para Negara. Walaupun demikian, kebiasaan hukum internasional dapat mencerminkan arah kepentingan Negara berdasarkan kecenderungan untuk berperilaku teratur pada praktik-praktik tertentu. Perjanjian internasional memuat doktrin pacta sunt servanda sebagai norma khusus yang mengemban kewajiban hukum. ${ }^{56}$ Menurut hukum internasional, suatu perjanjian akan meningkatkan level kepatuhan para pihak dengan menambahkan kekuatan normatifnya dan juga tingkat kesadaran hukum Negara. Ketika Negara memasuki sebuah perjanjian yang dimaksud untuk diatur oleh hukum perjanjian internasional, saat itu Negara menempatkan dirinya dibawah kewajiban hukum internasional untuk menjadi patuh. ${ }^{57}$ Maksim opiniojuris yang diacu sebagai norma psikologis kebiasan hukum internasional berbeda dengan doktrin pacta sunt servanda dalam perjanjian internasional yang terwujud dalam asas consent to be bound.

Sebagai perjanjian multilateral disertai dengan frekuensi pertemuan yang intens dan panjang, perjanjian General Agreement on Tariffs and Trade/GATT lebih menguntungkan secara kolektif daripada perjanjijan dagang bilateral. Kolektivitas tersebut didasarkan pada timbulnya masalah umum yang dirasakan bersama dan ketidakmampuan perjanijan bilateral untuk memaksimalkan potensi surplus perdagangan. Perjanjian bilateral dapat berubah-ubah setiap waktu tergantung kepentingan eksklusif kedua pihak, sedangkan perjanijan multilateral dapat mengakomodir kepentingan bersama secara lebih komprehensif dan transparan dalam perdagangan sehingga dapat dipastikan sumber hukumnya. ${ }^{58}$

Perjanjian GATT memuat konsensus dari para peserta dan oleh sebab itu mengikat bagi para Negara-Negara yang menyatakan persetujuannya. GATT telah menentukan pedoman perdagangan internasional antar Negara anggota. Konsensus atas perdangan internasional dapat dilihat salah satunya dalam pengesahan pendirian WTO.

Perspektifekonomi terhadaphukum publik internasional selanjutnya akan menganalisis norma kedua setelah Negara, yaitu perjanjian multilateral perdagangan GATT dan secara spesifik menganalisis Agreement Technical Barrier to Trade. Analisis ekonomi terhadap perdagangan internasional memandang bahwa campur tangan pemerintah menurunkan kesejahteraan secara global. ${ }^{59}$ Intervensi tersebut terkait dengan kebijakan pemerintah yang semata-mata bersikap satu arah untuk

56 The Vienna Convention on The Law of Treaties Article 26: "Every treaty in force is binding upon the parties to it and must be performed by them in good faith". Jack L. Goldsmith, Eric A. Posner, op.cit., p. 83.

57 Jack L. Goldsmith, Eric A. Posner, Ibid.

58 Jack L. Goldsmith, Eric A. Posner, Ibid., p. 145.

59 "The normative economics of international trade suggests that government intervention in trade flows generally reduces global welfare." Mitchell Polinsky dan Steven Shavell (Ed), op.cit., p. 786. 
memaksimalkan kesejahteraan sendiri, atau pengaruh internal. Beberapa contoh yang dapat dikemukakan sebagai faktor internalitas adalah seperti pengenaan tarif optimum, bea dan pajak barang bagi konsumen barang impor atau pengendalian impor untuk menjaga rasio ekspor lebih maksimal. Model pedagangan internasional membutuhkan minimal dua Negara sebagai pelaku. Apabila asumsi diatas juga diterapkan untuk Negara lain, maka akan berdampak pada kerjasama internasional yang tidak seimbang.

Dampak tersebut teridentifikasi sebagai faktor eksternal yang mempengaruhi keseimbangan atau ekuilibrium perdagangan. Munculnyafaktoreksternalyangtidakkoperatif dapat diatasi dengan kesepakatan perjanjian internasional. ${ }^{60}$ Perjanjian perdagangan internasional dapat mencapai keseimbangan melalui penerapan prinsip non-diskriminasi perdagangan seperti perlakuan national treatment atau most-favoured nation. ${ }^{61}$ Dalam upaya untuk mencapai dan menjaga ekuilibrium perdagangan, skema perjanjian GATT mengatur kebijakan hambatan tarif dan hambatan non-tarif. Kebijakan tarifmerupakan instrumen utama perdagangan bebas yang dapat diukur secara normatif salah satunya berdasarkan konsensi penurunan tarif (Pasal II GATT). Kebijakan non-tarif merupakan ukuran internal (internal measure) yang memuat regulasi dan persyaratan diskriminatif bagi produk impor guna memberi proteksi terhadap produksi dalam negeri.

Perlakuan internal yang dirujuk dari Pasal III GATT ini mengandung prinsip national treatment, dilarang bertindak diskriminasi terhadap Negara lain melalui instrumen internal measures yang terkualifikasi sebagai kebijakan non-tarif. Tidak ada hambatan atas suatu regulasi dikenakan pada impor kecuali itu juga dikenakan pada produsen dalam negeri yang serupa dengan produk impor. ${ }^{62}$ Begitu pula dengan penerapan Pasal XX GATT yang memuat klausula pengecualian atau escape clause. Negara Anggota dapat meninggalkan kewajiban dan aturan GATT untuk alasan-alasan perlindungan lingkungan dan kesehatan atau keamanan nasional. Internalisasi kebijakan domestik menurut Pasal III dan perkecualian kewajiban dalam Pasal XX dirasa memerlukan suatu disiplin baru untuk mengklarifikasi internal measures yang dimaksud sebagai perlakuan national treatment. Klarifikasi tersebut terwujud dalam perjanjian Agreement on Technical Barrier to Trade yang mengatur standardisasi.

Analisis ekonomi menujukkan bahwa standardisasi saling menguntungkan bagi negara-negara yang berkompromi untuk

\footnotetext{
60 "As in most other areas of international law, therefore, the role of international agreements is to overcome the externality problem." Mitchell Polinsky dan Steven Shavell (Ed), Ibid., p. 788.

61 "In simple term, most-favoured nation treatment prohibit a country from discriminating between countries. The national treatment prohibit a country from discriminating againts other countries." Dalam Peter Van den Bosche, The Law and Policy of WTO Text, Case and Materials, (New York: Cambridge University Press, 2005), p. 308.

62 Mitchell Polinsky dan Steven Shavell (Ed), op.cit., p. 793.
} 
mengurangi hambatan teknis. ${ }^{63}$ Kebijakan regulasi, persyaratan teknis, standardisasi dan penilaian kesesuaian akan bekerja melayani pasar melalui perlindungan lingkungan, keselamatan konsumen, kemanan dan kesehatan publik. Tanpa ada kebijakan ini, biaya kerugian sosial (social cost) akan lebih besar daripada keuntungan ekonomis semata.

Standardisasi masih memiliki setidaknya dua keuntungan dalam meningkatkan efisiensi waktu dan biaya. Pertama, bahwa standar didesain untuk memfasilitasi pertukaran informasi dan menjaga jaminan kualitas. $^{64}$ Begitu pula alur komunikasi yang semakin efisien antara distributor dan konsumen terkait karakteristik produk akan membantu peningkatan akumulasi transaksi di pasar. Kedua, proses standardisasi dapat mengurangi biaya ketidakpastian yang kerap dialami konsumen. ${ }^{65}$ Standardisasi membantu konsumen melakukan perbandingan karakteristik produksi dan juga dapat meningkatkan elastisitas preferensi bagi konsumen untuk produk sejenis.

\section{Simpulan}

1. Analisis ekonomi terhadap hukum perdagangan internasional terbagi menjadi dua analisis mendasar, yaitu analisis deskriptif dan analisis normatif.
Analisis deskriptif mengasumsikan perilaku rasional Negara untuk mencapai kemakmuran yang sebesar-besarnya melalui perjanjian dagang internasional. Secara normatif, dapat dianalisis melalui perjanjian dagang multilateral, yaitu General Agreement on Tariffs and Trade (GATT) yang juga mengatur Agreement on Technical Barrier to Trade. Dalam analisis ekonomi, perjanjian multilateral merupakan pilihan sikap yang efisien karena menghasilkan perjanjian yang kolektif dan universal. Dengan demikian, alokasi norma, kaidah dan proses serta kelembagaan program standardisasi Undang-undang No.7 Tahun 2014 tentang Perdagangan adalah sinkron dengan Agreement on Technical Barrier to Trade.

2. Standardisasi dapat diterapkan secara efektif dalam mengurangi dampak hambatan teknis perdagangan. Esensi dari kaidah ini bekerja sebagai instrumen hukum dalam pasar bebas melalui perlindungan lingkungan, keselamatan konsumen, kemanan dan kesehatan publik. Instrumen standardisasi juga membantu konsumen membandingkan karakteristik produksi dan menambah preferensi bagi konsumen untuk produk sejenis.

63 John S. Wilson, Standards, Regulation and Trade. WTO Rules and Developing Country Concerns, Development, Trade And The WTO, A Handbook, (Washington DC: World Bank Publisher, 2002), p. 428.

64 John S. Wilson, Ibid. "Standards are designed to facilitate information exchange, ensure quality, and achieve the provision of public goods."

65 John S. Wilson, Ibid. "The process of standardization may reduce the costs of uncertainty (as measured by time an effort devoted to search).” 


\section{DAFTAR PUSTAKA}

\section{Buku}

Appleton, Arthur. The World Trade Organization: Legal, Economic and Political Analysis Vol.1. New York: Springer Science+Business, 2005.

Chandrawulan, An An. Hukum Perusahaan Multinasional, Liberalisasi Hukum Perdagangan Internasional dan Hukum Penanaman Modal. Bandung: Alumni, 2011.

Cooter, Robert and Thomas Ulen. Law and Economics Sixth Edition. Boston: Pearson, 2012.

Deardorff, Alan V. and Robert M. Stern. Measurement of Non Tariff Barriers. Ann Arbor: The University of Michigan Press, 2011.

Gautama, Sudargo. Pengantar Hukum Perdata Internasional. Cetakan Ke-5. Bandung: Binacipta, 1987.

Goldsmith, Jack L., and Eric A. Posner. The Limits of International Law. New York: Oxford University Press, 2005.

Huala, Adolf. Hukum Perdagangan Internasional. Jakarta: RajaGrafindo Persada, 2013.

Koebele, Michaels. Max Planck Commentaries on World Trade Law Vol. 3. Leiden: Koninklijke Brill NV, 2007.

Polinsky, Mitchell dan Steven Shavell (Ed). Handbook of Law and Economics Vol.1. Oxford: Elsevier, 2007.
Sanson, Michelle. Essential International Trade Law. Sydney: Cavendish, 2002.

Shavell, Steven. Foundation of Economic Analysis of Law. Cambridge, Massachusetts: The Belknap Press of Harvard University Press, 2004.

Stiglitz, Joseph E. and Andrew Charlton. Fair Trade For All How Trade Can Promote Development. New York: Oxford University Press Inc., 2005.

Trebilcock, Michael J. and Robert Howse. The Regulation of International Trade Second Edition. London: Routledge, 1999.

Wie, Thee Kian (editor). Pelaku Berkisah Ekonomi Indonesia 1950-an sampai 1990-an. Cetakan Ke-1. Jakarta: Penerbit Buku Kompas, 2005.

Bosche, Peter Van den. The Law and Policy of WTO Text, Case and Materials. New York: Cambridge University Press, 2005.

Wilson, John S. Standards, Regulation and Trade. WTO Rules and Developing Country Concerns Development, Trade And The WTO, A Handbook. Washington DC: World Bank Publisher, 2002.

\section{Peraturan Perundang-undangan}

Undang-undang Republik Indonesia Nomor 7 Tahun 2014 tentang Perdagangan. 